\title{
Differences in Plasma Cytokine Levels between Elite Kayakers and Nonathletes
}

\author{
G. F. Borges, ${ }^{1,2}$ L. Rama, ${ }^{1}$ S. Pedreiro, ${ }^{3}$ F. Alves, ${ }^{4}$ A. Santos, ${ }^{1}$ \\ A. Massart, ${ }^{1}$ A. Paiva, ${ }^{3}$ and A. M. Teixeira ${ }^{1,5}$ \\ ${ }^{1}$ Center for Sports and Physical Activity, Sport Sciences and Physical Education School, \\ University of Coimbra, 3040-156 Coimbra, Portugal \\ ${ }^{2}$ Health and Biotechnology Institute, Federal University of Amazonas, 69460-000 Coari, AM, Brazil \\ ${ }^{3}$ Center of Histocompatibility, 3001-301 Coimbra, Portugal \\ ${ }^{4}$ Human Kinetics School, Technical University of Lisbon, 1499-002 Lisbon, Portugal \\ ${ }^{5}$ Estádio Universitário, Pavilhão 3, Sta. Clara, 3040-156 Coimbra, Portugal \\ Correspondence should be addressed to A. M. Teixeira; ateixeira@fcdef.uc.pt
}

Received 15 April 2013; Accepted 14 May 2013

Academic Editor: Akito Tanoue

Copyright (C) 2013 G. F. Borges et al. This is an open access article distributed under the Creative Commons Attribution License, which permits unrestricted use, distribution, and reproduction in any medium, provided the original work is properly cited.

Regular moderate exercise has been shown to have anti-inflammatory effects that help prevent several chronic diseases. However, the effects of chronic training an elite athletes have not been the focus of much research. This study aimed to determine whether there were differences in cytokine levels (IL-1 $\beta$, IL-1ra, IL- 6 , IL-10, IL-18, IFN- $\gamma$, and TNF- $\alpha$ ) in circulating peripheral blood (PB) between elite kayakers and nonathletes. Subjects were 13 elite male kayakers, aged $20.0 \pm 3$ years, with average body mass of $75.0 \pm 7.9 \mathrm{~kg}$ and $177.3 \pm 7.1 \mathrm{~cm}$ height and with $\mathrm{VO}_{2 \max }$ of $58.3 \pm 7.8 \mathrm{~mL} \cdot \mathrm{kg}^{-1} \cdot \mathrm{min}^{-1}$. The nonathletes were $7 \mathrm{men}$, aged $18.2 \pm 1.1$ years, body mass of $81.3 \pm 13.8 \mathrm{~kg}$, and $171.9 \pm 4.5 \mathrm{~cm}$ height. Blood samples were collected after six weeks of offtraining and before the start of a new training season. PB leukocyte populations were determined by flow cytometry. Cytokine levels were quantified by ELISA. When nonathletes were compared with the kayakers, the latter exhibited lower plasma concentrations of IL-1 $\beta$, IL-18, and IFN- $\gamma$ as well as a lower concentration of IL-1ra. Positive correlations between IL-18 and B cells in the athletes were also found. These results seem to reinforce the anti-inflammatory role of regular training.

\section{Introduction}

Regular exercise has been associated with protection against mortality from all causes, primarily to protect against atherosclerosis, type 2 diabetes, colon and breast cancer [1]. In addition, exercise training is effective in treating patients with ischemic heart disease [2], heart failure [3], type 2 diabetes [4], and chronic obstructive pulmonary disease [5]. The protective effect of exercise against diseases has been attributed to the anti-inflammatory effect of exercise practiced regularly causing endocrine effects that directly mediate the antiinflammatory response of cytokines [6, 7]. Cytokines, which are bioactive polypeptides, are important in cell regulation. They are messengers that regulate and bring information to the cells of the immune system [7]. When a chronic systemic low grade inflammation occurs, proinflammatory and antiinflammatory circulating interleukin levels are increased two- to four-fold and a small elevation in the number of circulating neutrophils and natural killer cells $[8,9]$ is also seen.

Prolonged exercise, on the other hand, has been associated with a transient depression in the immune system [10]. Both prolonged exercise and competitive periods are able to impair the athletes immune function. The number and functional capacity of circulating leukocytes can be reduced when repeated series of strenuous exercise are performed. The reason for this is probably related to the increased levels of stress hormones released during exercise [11]. It is also known that acute administration of steroid glucocorticoids $[12]$ and exercise $[13,14]$ may cause a temporary inhibition of interferon gamma $(\mathrm{IFN}-\gamma)$ production. It has been suggested 
that this may be an important mechanism by which exercise leads to a depressed immune function $[13,14]$. Our group has recently shown [15] that the frequency of monocytes and dendritic cells producing IL- $1 \beta$, IL- 12 , IFN- $\gamma$, TNF- $\alpha$, and MIP- $1 \beta$ decreased in highly trained swimmers throughout a training season. It has been proposed that the anti-inflammatory effects of exercise [16], possibly mediated by increased levels of IL-10 in the athletes, would be able to induce a degree of immunosuppression that could contribute to an increased susceptibility to upper respiratory tract infections during periods of intensified training.

At rest, the immune function of athletes seems to be similar to nonathletes $[10,11]$. However we need more data on the levels of circulating cytokines and leukocyte subpopulations in these two populations. The aim of this study was to investigate whether successive years of training and competition at the highest level would be able to induce longlasting substantial differences in peripheral blood circulating cytokine levels (IL-1 $\beta$, IL-1ra, IL-6, IL-10, IL-18, IFN- $\gamma$, and TNF- $\alpha$ ) and leukocyte subpopulations by comparing a group of elite kayakers with age-matched nonathletes.

\section{Materials and Methods}

2.1. Participants Characteristics. The elite athlete sample was comprised of 13 elite kayakers, with at least 3 years of kayak training at elite level, mean age $20 \pm 3$ years, with an average body mass of $75.0 \pm 7.9 \mathrm{~kg}, 177.3 \pm 7.1 \mathrm{~cm}$ in height, and a $\mathrm{VO}_{2 \max }$ of $58.3 \pm 7.8 \mathrm{~mL} \cdot \mathrm{kg}^{-1} \cdot \mathrm{min}^{-1}$. The control group consisted of seven healthy men who did not practiced regular physical activity and with a mean age of $18.2 \pm 1.1$ years, body mass of $81.3 \pm 13.8 \mathrm{~kg}$, and $171.9 \pm 4.5 \mathrm{~cm}$ height. After oral and written explanation, written consent was obtained and the experimental protocol approved by the Ethics and Human Subjects Review Board at the Faculty of Sports Science and Physical Education, University of Coimbra.

2.2. Venous Blood Sampling. For this study, a venous blood sample of the athletes and controls was taken in November, during a specific training period where kayakers worked out with reduced loads and intensities, after an off season transitional period of six weeks, which would be the start of a new training season.

For this study, $20 \mathrm{~mL}$ of peripheral blood was collected by venipuncture of the antecubital vein, after 48 hours of rest from the last training session. Peripheral blood leukocytes levels, including neutrophils, lymphocytes, and monocytes, were determined using a cell counter (Beckman Coulter T66, USA).

2.3. Flow Cytometry. Lymphocyte subsets were determined by flow cytometry, including the total number of T lymphocytes $\left(\mathrm{CD}^{+}\right)$and their T-cell subpopulations $\mathrm{CD}^{+} \mathrm{CD}^{+}$and $\mathrm{CD}^{+} \mathrm{CD}^{+}$, B lymphocytes $\left(\mathrm{CD} 19^{+}\right)$, and natural killer cells (NK) $\left(\mathrm{CD}^{-} \mathrm{CD}^{+} 6^{+}\right)$. Staining of the cells was performed using the LYMPHOGRAM kit (CYT-C001, Cytognos, Spain) according to the manufacturer's instructions. The stained cells were analyzed on a FACScan flow cytometer (FACSCalibur, BD, San Jose, CA, USA) using CellQuest software
(BD Biosciences). Data were analyzed using the software "Infinicyt" (Cytognos, Spain).

2.4. Enzyme Immunoassay (ELISA). The concentrations of cytokines IL-1, IL-1RA, IL-6, IL-10, IL-18, TNF- $\alpha$, and IFN- $\gamma$ in plasma were determined by sandwich ELISA kits, according to the manufacturer's instructions (Invitrogen, Nivelles, Belgium).

2.5. Statistical Analysis. For this study we considered the mean and standard deviation values. Because according to the Shapiro-Wilk the samples were not normally distributed, we used the Mann-Whitney $U$ test to detect differences between athletes and controls and the Spearman correlation test to study the correlations between variables. The value of significance was set at $P<0.05$. Statistical analysis was performed using the SPSS software for Mac (version 19.0).

\section{Results}

Lower levels of IL- $1 \beta$, IL-1ra, IL-18, and IFN- $\gamma$ plasma concentrations were found for kayakers when compared to the nonathletes. The same was observed for the NK cell population. No differences for IL-10 and IL-6 plasma concentrations were found. The total number and percentage of leukocytes, monocytes, granulocytes, T lymphocytes, and their subpopulations and B lymphocytes did not differ between groups. A compilation of the data is presented in Table 1.

Using the Spearman test (Rho), correlations between cells (total leukocytes, lymphocytes, T lymphocytes, and subsets) and plasma interleukin concentrations were found for the kayakers. Leukocytes (WBC) positively correlated with IL-1ra $(\rho=0.67, P<0.05)$ and IL-18 $(\rho=0.50, P<0.05)$. Negative correlations were found between the $\% \mathrm{CD}^{+}$and IFN- $\gamma(\rho$ $=-0.54, P<0.05)$ and the total number of $\mathrm{CD}^{+} \mathrm{CD}^{+}$cells and IL-1 $\beta(\rho=-0.47, P<0.05)$. Correlations were also found between the \% of B cells and IL-18 $(\rho=0.65, P<0.05)$ and IFN- $\gamma(\rho=-0.52, P<0.05)$. The total number of $\mathrm{B}$ lymphocytes also correlated with IL-18 $(\rho=0.69, P<0.05)$. All correlation results are shown in Table 2.

\section{Discussion}

The results of the present study show that plasma concentrations of IL-1 $\beta$, IL-1ra, IL-18, and IFN- $\gamma$ were lower in the kayakers compared with the nonathletes (Table 1). These results seem to confirm the anti-inflammatory effect of training [17] and consequent inhibition of IFN- $\gamma$ production by $\mathrm{T}$ cells $[13,14]$. Kayakers also showed slightly lower levels of TNF- $\alpha$ than controls.

Our results showed that the concentration of IFN- $\gamma$ in peripheral blood of athletes was positively correlated with the number of B lymphocytes and inversely correlated with circulating levels of T lymphocytes (Table 2). The mechanism of IFN- $\gamma$ production by B lymphocytes is still under study however it is suggested that IFN- $\gamma$ produced by B cells has an amplifying effect on the Thl cell response [18]. The significant differences in IFN- $\gamma$ plasma concentration between kayakers and the control group could occur due to exercise being able 
TABLE 1: Peripheral blood leukocyte and plasma cytokine levels in elite kayakers and nonathletes.

\begin{tabular}{|c|c|c|c|}
\hline & $\begin{array}{l}\text { Kayakers } \\
(N=13)\end{array}$ & $\begin{array}{r}\text { Controls } \\
(N=7)\end{array}$ & $P$ \\
\hline $\begin{array}{l}\text { Total Leukocytes } \\
\left(10^{9} / \mathrm{L}\right)\end{array}$ & $9.40 \pm 1.63$ & $8.41 \pm 1.88$ & 0.24 \\
\hline Monocytes $\left(10^{9} / \mathrm{L}\right)$ & $0.41 \pm 0.16$ & $0.66 \pm 0.69$ & 0.23 \\
\hline$\%$ monocytes & $4.61 \pm 1.88$ & $7.17 \pm 6.63$ & 0.55 \\
\hline Neutrophils $\left(10^{9} / \mathrm{L}\right)$ & $5.60 \pm 1.45$ & $5.31 \pm 1.36$ & 0.32 \\
\hline$\%$ neutrophils & $63.0 \pm 6.2$ & $63.1 \pm 5.2$ & 0.96 \\
\hline Lymphocytes $\left(10^{9} / \mathrm{L}\right)$ & $2.33 \pm 0.46$ & $2.41 \pm 0.69$ & 0.41 \\
\hline \% lymphocytes & $25.2 \pm 5.4$ & $28.7 \pm 6.1$ & 0.91 \\
\hline $\mathrm{CD}^{+} \mathrm{T}$ cells $\left(10^{9} / \mathrm{L}\right)$ & $1.53 \pm 0.47$ & $1.76 \pm 0.47$ & 0.22 \\
\hline$\% \mathrm{CD}^{+} \mathrm{T}$ cells & $66.2 \pm 16.2$ & $74.4 \pm 11.7$ & 0.15 \\
\hline $\begin{array}{l}\mathrm{CD}^{+} \mathrm{CD} 4^{+} \mathrm{T} \text { cells } \\
\left(10^{9} / \mathrm{L}\right)\end{array}$ & $0.86 \pm 0.28$ & $0.95 \pm 0.28$ & 0.35 \\
\hline$\% \mathrm{CD}^{+} \mathrm{CD}^{+} \mathrm{T}$ cells & $56.3 \pm 6.3$ & $53.7 \pm 5.9$ & 0.22 \\
\hline $\begin{array}{l}\mathrm{CD}^{+} \mathrm{CD}^{+} \mathrm{T} \text { cells } \\
\left(10^{9} / \mathrm{L}\right)\end{array}$ & $0.54 \pm 0.18$ & $0.63 \pm 0.21$ & 0.22 \\
\hline $\begin{array}{l}\% \mathrm{CD}^{+} \mathrm{CD}^{+} \mathrm{T} \text { cells } \\
\left(10^{9} / \mathrm{L}\right)\end{array}$ & $34.9 \pm 5.5$ & $35.5 \pm 3.8$ & 0.45 \\
\hline $\begin{array}{l}\mathrm{CD}^{-} \mathrm{CD}^{-} 9^{+} \mathrm{B} \text { cells } \\
\left(10^{9} / \mathrm{L}\right)\end{array}$ & $0.40 \pm 0.13$ & $0.35 \pm 0.13$ & 0.22 \\
\hline$\% \mathrm{CD}^{-} \mathrm{CD} 9^{+} \mathrm{B}$ cells & $17.2 \pm 4.6$ & $14.4 \pm 4.0$ & 0.10 \\
\hline $\begin{array}{l}\mathrm{CD}^{-}{ }^{-} \mathrm{CD} 6^{+} \mathrm{NK} \text { cells } \\
\left(10^{9} / \mathrm{L}\right)\end{array}$ & $0.06 \pm 0.03$ & $0.10 \pm 0.04$ & $0.02^{*}$ \\
\hline $\begin{array}{l}\% \mathrm{CD}^{-} \mathrm{CD}^{2} 6^{+} \mathrm{NK} \\
\text { cells }\end{array}$ & $2.46 \pm 0.87$ & $5.28 \pm 3.31$ & $0.02^{*}$ \\
\hline $\mathrm{IL}-1 \beta \mathrm{pg} / \mathrm{mL}$ & $4.61 \pm 2.18$ & $8.74 \pm 3.16$ & $0.03^{*}$ \\
\hline IL-1ra pg/mL & $20.58 \pm 7.09$ & $78.67 \pm 84.62$ & $0.01^{*}$ \\
\hline IL-6 pg/mL & $14.18 \pm 5.83$ & $11.33 \pm 4.28$ & 0.19 \\
\hline IL-10 pg/mL & $16.53 \pm 14.90$ & $9.05 \pm 3.52$ & 0.20 \\
\hline IL-18 pg/mL & $354.13 \pm 83.70$ & $1758.86 \pm 1794.27$ & $<0.01^{*}$ \\
\hline IFN- $\gamma$ pg/mL & $6.74 \pm 5.06$ & $13.86 \pm 3.68$ & $0.01^{*}$ \\
\hline TNF- $\alpha$ pg/mL & $31.38 \pm 33.41$ & $35.54 \pm 13.36$ & 0.11 \\
\hline
\end{tabular}

Values are expressed in mean and standard deviation. ${ }^{*} P<0.05$.

to cause a temporary inhibition of IFN- $\gamma$ production by $\mathrm{T}$ and $B$ lymphocytes, and it has been suggested that this may be an important mechanism by which exercise induces a depression in immune system function $[13,14]$.

In the present study, NK cells were lower in the kayakers than in the control group. A lower value of $\mathrm{CD}^{-} \mathrm{CD} 56^{+}$cell counts, lower value of CD56 ${ }^{\mathrm{dim}}$ subpopulation, and reduced expression of the IFN- $\gamma$ receptor NK cell expression were also found in swimmers during a training season and could partially explain the higher frequency of upper respiratory symptoms (URS) observed during the training phases of increased volume and intensity [19]. The effect of exercise intensity in the cytolytic activity of NK cells seems to present a dual-phase effect, with initial gain followed by delayed suppression [20,21]. Many studies support the increase in NK cell numbers in the circulation during progressive exercise, as well the fast return of NK cells towards preexercise levels during subsequent recovery $[22,23]$. The alterations that occur after a set of prolonged exercises may lead to natural suppression of the NK and T cells activity, which could potentially present benefits to the transplanted patients when rejection risk is concerned $[20,21]$ but could increase susceptibility to URS in athletes subjected to high intensity training.

Initially it was believed that the T helper I (Th1), $\mathrm{CD}^{+}$ cytotoxic lymphocytes and NK cells were the only cell types producing IFN- $\gamma$. Currently there is evidence that other cells such as B cells, NKT cells, and professional antigenpresenting cells (APCs) secrete IFN- $\gamma$ [24]. IFN- $\gamma$ production is controlled by cytokines secreted by APCs, most notably IL12 and IL-18. These cytokines serve as a bridge to link infection with IFN $-\gamma$ production in the innate immune response $[24,25]$. In macrophages, $\mathrm{NK}$, and $\mathrm{T}$ cells, the combination of IL-12 and IL-18 stimulation further increases IFN- $\gamma$ production. In our study, IL-18 concentration correlated positively with both the percentage and absolute numbers of B cells $\left(\mathrm{CD}^{-} \mathrm{CD} 19^{+}\right)$(Table 2). This result seems to be important to the health of athletes, because recent studies have shown that IL-18 is involved in the response and recruitment of B lymphocyte cells, specifically the activation of B cells residing in the extrafollicular plasma zone of the spleen, and IL18 production is regulated by $\mathrm{NK} \mathrm{T}$ cells $\left(\mathrm{CD}^{+} \mathrm{CD} 56^{-}\right)$ preventing the formation of mature marginal centers [26]. In another study, with different B lymphocytes subpopulations, in normal and chronic proliferative disorders, it was suggested that a disturbed expression of IL-18 and/or of its receptor on neoplastic B cells could in certain cases facilitate the growth of tumors, as they may affect antitumor effector mechanisms because of poor regulation of IL-18 production [27]. Our results also showed that in athletes, submitted to high level intensity exercise, the plasma concentration of IL18 was lower than in individuals who do not exercise regularly. It was postulated that exercise may lower IL-18 concentration via insulin-signaling modification [28]. A significant decrease in the concentration of IL-18 has been observed in cyclists 24 hours after completing a $230 \mathrm{~km}$ road race [29]. On the other hand, increased concentrations of IL-18 have been associated with several components of the metabolic syndrome and used as a factor in predicting diabetes, atherosclerosis, and cardiovascular disorders [30-32].

In the kayakers, a significant inverse correlation between IL- $1 \beta$ and $\mathrm{CD}^{+} \mathrm{CD}^{+}$cells was also found. The $\mathrm{CD}^{+} \mathrm{CD}^{+}$ cells are normally exposed during an inflammatory response to IL-1 $\beta$, IL-6, and IL-23 that arise especially in ischemic lesions [33]. It has been shown that the proinflammatory cytokines determine the susceptibility of human CD8 T cells to Fas-mediated activation-induced cell death through modulation of FasL and c-FLIP(S) expression [34]. Recent findings showing that cytokines act on all lymphocytes within reactive lymph nodes during active immune responses indicate that proinflammatory cytokines produced by APCs are likely to affect the function of all reactive $\mathrm{T}$ cells [35]. According to Gleeson and collaborators [16], the long hours of hard training that elite athletes undertake induce an antiinflammatory state that may cause a degree of immunosuppression that could make them more susceptible to minor infections. 
TABLE 2: Spearman correlations $(\rho)$ between peripheral blood leukocyte subpopulations and plasma cytokine concentrations in elite kayakers $(n=13)$.

\begin{tabular}{|c|c|c|c|c|c|c|c|}
\hline \multirow{2}{*}{ Cells } & \multirow[b]{2}{*}{ IL-1 $\beta \mathrm{pg} / \mathrm{mL}$} & \multicolumn{6}{|c|}{ Cytokines } \\
\hline & & IL-1ra pg/mL & IL-6 pg/mL & $\mathrm{IL}-10 \mathrm{pg} / \mathrm{mL}$ & IL-18 pg/mL & IFN- $\gamma \mathrm{pg} / \mathrm{mL}$ & TNF- $\alpha$ pg $/ \mathrm{mL}$ \\
\hline $\mathrm{WBC}\left(10^{3} / \mu \mathrm{L}\right)$ & $0.22(0.23)$ & $0.67^{*}(<0.01)$ & $-0.03(0.45)$ & $0.03(0.46)$ & $0.50^{*}(0.04)$ & $0.19(0.27)$ & $0.08(0.39)$ \\
\hline$\% \mathrm{LY}$ & $-0.42(0.07)$ & $-0.05(0.42)$ & $-0.37(0.11)$ & $-0.20(0.26)$ & $-0.25(0.20)$ & $-0.40(0.09)$ & $-0.25(0.20)$ \\
\hline $\operatorname{LY}\left(10^{3} / \mu \mathrm{L}\right)$ & $-0.18(0.27)$ & $0.39(0.08)$ & $-0.24(0.22)$ & $-0.15(0.32)$ & $0.11(0.36)$ & $-0.10(0.36)$ & $-0.09(0.38)$ \\
\hline$\% \mathrm{CD}^{+}$ & $-0.31(0.14)$ & $-0.22(0.23)$ & $-0.18(0.27)$ & $-0.16(0.30)$ & $-0.34(0.12)$ & $-0.54^{*}(0.03)$ & $-0.04(0.44)$ \\
\hline $\mathrm{CD}^{+}($cell $/ \mu \mathrm{L})$ & $-0.44(0.06)$ & $0.23(0.22)$ & $-0.33(0.14)$ & $-0.11(0.36)$ & $0.03(0.45)$ & $-0.27(0.19)$ & $0.14(0.32)$ \\
\hline$\% \mathrm{CD}^{+} \mathrm{CD}^{+}$ & $0.30(0.15)$ & $0.03(0.45)$ & $0.12(0.35)$ & $-0.06(0.41)$ & $-0.25(0.19)$ & $0.12(0.35)$ & $0.13(0.34)$ \\
\hline $\mathrm{CD}^{+} \mathrm{CD}^{+}($cell $/ \mu \mathrm{L})$ & $-0.32(0.14)$ & $0.21(0.24)$ & $-0.30(0.16)$ & $-0.20(0.26)$ & $-0.01(0.47)$ & $-0.35(0.13)$ & $0.16(0.30)$ \\
\hline$\% \mathrm{CD}^{+} \mathrm{CD}^{+}$ & $-0.29(0.16)$ & $-0.09(0.38)$ & $0.01(0.50)$ & $0.07(0.41)$ & $0.31(0.14)$ & $-0.04(0.49)$ & $0.01(0.50)$ \\
\hline $\mathrm{CD}^{+} \mathrm{CD}^{+}(\mathrm{cell} / \mu \mathrm{L})$ & $-0.47^{*}(0.04)$ & $0.18(0.27)$ & $-0.11(0.36)$ & $0.14(0.32)$ & $0.12(0.34)$ & $-0.08(0.39)$ & $0.21(0.24)$ \\
\hline$\% \mathrm{CD}^{-} \mathrm{CD}^{+} 9^{+}$ & $0.03(0.45)$ & $0.03(0.45)$ & $0.17(0.28)$ & $0.17(0.29)$ & $0.65^{*}(<0.01)$ & $0.52^{*}(0.04)$ & $0.07(0.40)$ \\
\hline $\mathrm{CD}^{-} \mathrm{CD} 9^{+}($cell $/ \mu \mathrm{L})$ & $-0.12(0.34)$ & $0.30(0.15)$ & $-0.10(0.37)$ & $0.05(0.43)$ & $0.69^{*}(<0.01)$ & $0.27(0.19)$ & $-0.02(0.46)$ \\
\hline$\% \mathrm{CD}^{-} \mathrm{CD}^{-} 6^{+}$ & $-0.16(0.29)$ & $0.23(0.21)$ & $-0.17(0.29)$ & $-0.20(0.26)$ & $-0.08(0.38)$ & $0.01(0.48)$ & $0.16(0.30)$ \\
\hline $\mathrm{CD}^{-} \mathrm{CD}^{-} 6^{+}(\mathrm{cell} / \mu \mathrm{L})$ & $-0.27(0.18)$ & $0.38(0.09)$ & $-0.24(0.22)$ & $-0.17(0.29)$ & $0.08(0.39)$ & $-0.04(0.44)$ & $0.05(0.43)$ \\
\hline
\end{tabular}

WBC: withe blood cells (leukocytes). ${ }^{*} P<0.05$.

\section{Conclusion}

When comparing athletes before a training period with a control group of not physically active persons, it was observed that athletes had a lower concentration of IL-1 $\beta$, IL-18, and IFN- $\gamma$ that are proinflammatory cytokines. These results appear to demonstrate the anti-inflammatory effects that regular training exercise practice seems to induce and could explain the beneficial effects of long-term regular exercise, manly in preventing chronic low grade inflammation and its consequences. As stated by Gleeson et al. [16], in the athletes, an increased risk of minor upper respiratory infections may be a small price to pay for the long-term health benefits of high level exercise practice.

\section{Conflict of Interests}

No conflict of interests is declared.

\section{Acknowledgments}

This study was financially supported by a grant, PTDC/DES/ $68647 / 2006$, from the Portuguese Foundation of Science and Technology (FCT). Grasiely Faccin Borges was sponsored with a full Doctorate scholarship abroad (no. 202441/2011-3) by CNPq (National Council of Scientific and Technological Development), Brazil.

\section{References}

[1] S. N. Blair, Y. Cheng, and J. Scott Holder, "Is physical activity or physical fitness more important in defining health benefits?" Medicine and Science in Sports and Exercise, vol. 33, no. 6, pp. S379-S399, 2001.

[2] J. A. Jolliffe, K. Rees, R. S. Taylor, D. Thompson, N. Oldridge, and S. Ebrahim, "Exercise-based rehabilitation for coronary heart disease," Cochrane Database of Systematic Reviews, no. 1, Article ID CD001800, 2001.
[3] M. F. Piepoli, "Exercise training meta-analysis of trials in patients with chronic heart failure (ExTraMATCH)," The British Medical Journal, vol. 328, no. 7433, pp. 189-192, 2004.

[4] N. G. Boulé, E. Haddad, G. P. Kenny, G. A. Wells, and R. J. Sigal, "Effects of exercise on glycemic control and body mass in type 2 diabetes mellitus: a meta-analysis of controlled clinical trials," The Journal of the American Medical Association, vol. 286, no. 10, pp. 1218-1227, 2001.

[5] Y. Lacasse, R. Goldstein, T. J. Lasserson, and S. Martin, "Pulmonary rehabilitation for chronic obstructive pulmonary disease," Cochrane Database of Systematic Reviews, no. 4, Article ID CD003793, 2006.

[6] C. Brandt and B. K. Pedersen, "The role of exercise-induced myokines in muscle homeostasis and the defense against chronic diseases," Journal of Biomedicine and Biotechnology, vol. 2010, Article ID 520258, 6 pages, 2010.

[7] Z. Zhang, L. Zhang, and J. Xu, "The effects of different exercise training mode on interleukins," Life Science Journal, vol. 4, no. 3, pp. 82-86, 2007.

[8] H. Bruunsgaard, S. Ladelund, A. N. Pedersen, M. Schroll, T. Jørgensen, and B. K. Pedersen, "Predicting death from tumour necrosis factor- $\alpha$ and interleukin-6 in 80-year-old people," Clinical and Experimental Immunology, vol. 132, no. 1, pp. 24-31, 2003.

[9] H. Brüünsgaard and B. K. Pedersen, "Age-related inflammatory cytokines and disease," Immunology and Allergy Clinics of North America, vol. 23, no. 1, pp. 15-39, 2003.

[10] M. Gleeson, "Immune function in sport and exercise," Journal of Applied Physiology, vol. 103, no. 2, pp. 693-699, 2007.

[11] M. Gleeson, "Immune system adaptation in elite athletes," Current Opinion in Clinical Nutrition and Metabolic Care, vol. 9, no. 6, pp. 659-665, 2006.

[12] J. A. Moynihan, T. A. Callahan, S. P. Kelley, and L. M. Campbell, "Adrenal hormone modulation of type 1 and type 2 cytokine production by spleen cells: dexamethasone and dehydroepiandrosterone suppress interleukin-2, interleukin-4, and interferon- $\gamma$ production in vitro," Cellular Immunology, vol. 184, no. 1, pp. 58-64, 1998. 
[13] G. I. Lancaster, S. L. Halson, Q. Khan et al., "Effects of acute exhaustive exercise and chronic exercise training on type 1 and type 2 T lymphocytes," Exercise Immunology Review, vol. 10, pp. 91-106, 2004

[14] H. Northofff, A. Berg, and C. Weinstock, "Similarities and differences of the immune response to exercise and trauma: the IFN- $\gamma$ concept," Canadian Journal of Physiology and Pharmacology, vol. 76, no. 5, pp. 497-504, 1998.

[15] J. M. Morgado, L. Rama, I. Silva et al., "Cytokine production by monocytes, neutrophils, and dendritic cells is hampered by long-term intensive training in elite swimmers," European Journal of Applied Physiology, vol. 112, no. 2, pp. 471-482, 2012.

[16] M. Gleeson, N. C. Bishop, D. J. Stensel, M. R. Lindley, and S. S. Mastana, "The anti-inflammatory effects of exercise: mechanisms and implications for the prevention and treatment of disease," Nature Reviews, Immunology, vol. 11, pp. 607-615, 2011.

[17] D. P. Harris, S. Goodrich, A. J. Gerth, S. L. Peng, and F. E. Lund, "Regulation of IFN- $\gamma$ production by B effector 1 cells: essential roles for T-bet and the IFN- $\gamma$ receptor," Journal of Immunology, vol. 174, no. 11, pp. 6781-6790, 2005.

[18] L. Rama, A. M. Teixeira, A. Matos et al., "Changes in natural killer cell subpopulations over a winter training season in elite swimmers," European Journal of Applied Physiology, vol. 113, no. 4, pp. 859-868, 2013.

[19] M. Gleeson and N. C. Bishop, "The T cell and NK cell immune response to exercise," Annals of Transplantation, vol. 10, no. 4, pp. 43-48, 2005.

[20] M. Kappel, N. Tvede, H. Galbo et al., "Evidence that the effect of physical exercise on NK cell activity is mediated by epinephrine," Journal of Applied Physiology, vol. 70, no. 6, pp. 2530-2534, 1991.

[21] R. J. Shephard and P. N. Shek, "Effects of exercise and training on natural killer cell counts and cytolytic activity: a meta-analysis," Sports Medicine, vol. 28, no. 3, pp. 177-195, 1999.

[22] S. G. Del Giacco and H. J. Malling, "Diversity of allergy and clinical immunology reunified by training at the EU level," Allergy, vol. 59, no. 6, pp. 575-576, 2004.

[23] K. Schroder, P. J. Hertzog, T. Ravasi, and D. A. Hume, "Interferon- $\gamma$ : an overview of signals, mechanisms and functions," Journal of Leukocyte Biology, vol. 75, no. 2, pp. 163-189, 2004.

[24] S. Akira, "The role of IL-18 in innate immunity," Current Opinion in Immunology, vol. 12, no. 1, pp. 59-63, 2000.

[25] S. L. Enoksson, E. K. Grasset, T. Hägglöf et al., "The inflammatory cytokine IL-18 induces self-reactive innate antibody responses regulated by natural killer T cells," Proceedings of the National Academy of Sciences of the United States of America, vol. 108, no. 51, pp. 1399-1407, 2011.

[26] I. Airoldi, L. Raffaghello, C. Cocco et al., "Heterogeneous expression of interleukin-18 and its receptor in B-cell lymphoproliferative disorders deriving from naive, germinal center, and memory B lymphocytes," Clinical Cancer Research, vol. 10, no. 1, pp. 144-154, 2004.

[27] N. P. Kadoglou, D. Perrea, F. Iliadis, N. Angelopoulou, C. Liapis, and M. Alevizos, "Exercise reduces resistin and inflammatory cytokines in patients with type 2 diabetes," Diabetes Care, vol. 30, no. 3, pp. 719-721, 2007.

[28] G. Neumayr, O. Ludwiczek, H. Hoertnagl et al., "The impact of prolonged strenuous endurance exercise on interleukin 18 and interleukin 18 binding protein in recreational cyclists," International Journal of Sports Medicine, vol. 26, no. 10, pp. 836-840, 2005.
[29] M. Yamaoka-Tojo, T. Tojo, K. Wakaume et al., "Circulating interleukin-18: a specific biomarker for atherosclerosis-prone patients with metabolic syndrome," Nutrition and Metabolism, vol. 8, no. 1, article 3, 2011.

[30] M. Trøseid, K. T. Lappegård, T. E. Mollnes, H. Arnesen, and I. Seljeflot, "The effect of exercise on serum levels of interleukin18 and components of the metabolic syndrome," Metabolic Syndrome and Related Disorders, vol. 7, no. 6, pp. 579-584, 2009.

[31] M. Trøseid, I. Seljeflot, and H. Arnesen, "The role of interleukin18 in the metabolic syndrome," Cardiovascular Diabetology, vol. 9, article 11, 2010.

[32] A. D. Schenk, T. Nozaki, M. Rabant, A. Valujskikh, and R. L. Fairchild, "Donor-reactive CD8 memory T cells infiltrate cardiac allografts within 24-h posttransplant in naive recipients," The American Journal of Transplantation, vol. 8, no. 8, pp. 16521661, 2008.

[33] A. Von Rossum, R. Krall, N. K. Escalante, and J. C. Choy, "Inflammatory cytokines determine the susceptibility of human CD8 T cells to Fas-mediated activation-induced cell death through modulation of FasL and c-FLIPS expression," The Journal of Biological Chemistry, vol. 286, no. 24, pp. 21137-21144, 2011.

[34] G. Perona-Wright, K. Mohrs, and M. Mohrs, "Sustained signaling by canonical helper $\mathrm{T}$ cell cytokines throughout the reactive lymph node," Nature Immunology, vol. 11, no. 6, pp. 520-526, 2010.

[35] A. M. W. Petersen and B. K. Pedersen, "The anti-inflammatory effect of exercise," Journal of Applied Physiology, vol. 98, no. 4, pp. 1154-1162, 2005. 

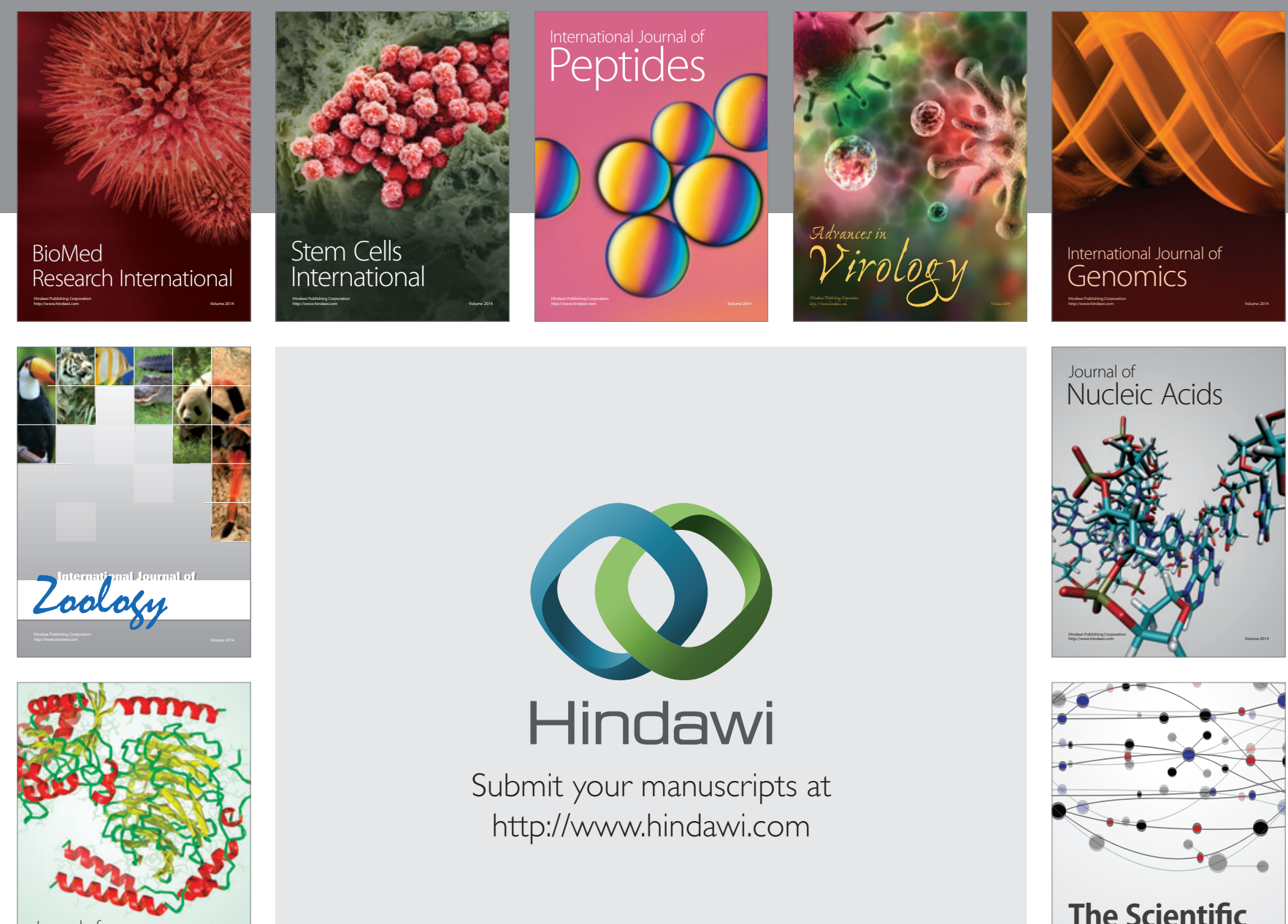

Submit your manuscripts at

http://www.hindawi.com

Journal of
Signal Transduction
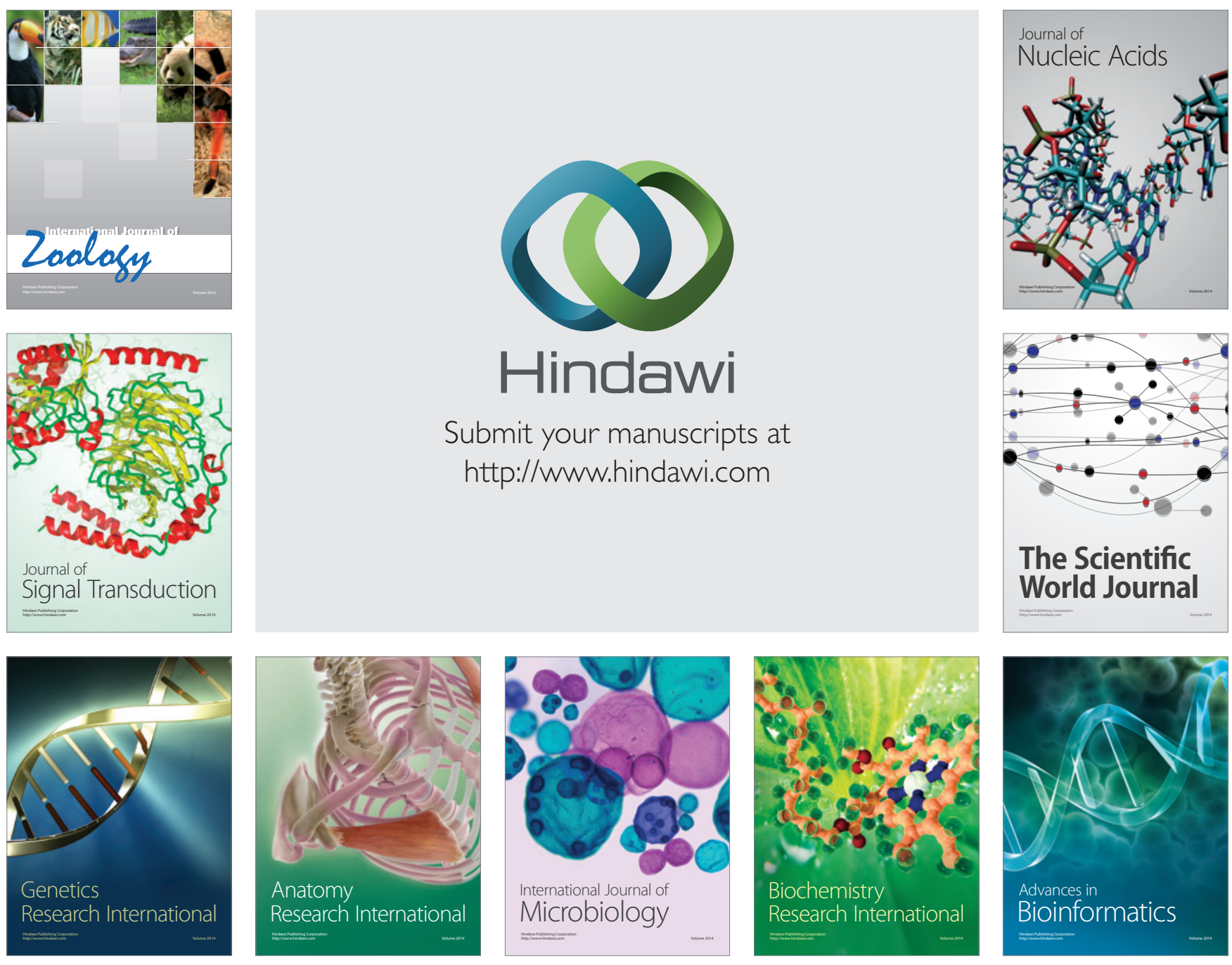

The Scientific World Journal
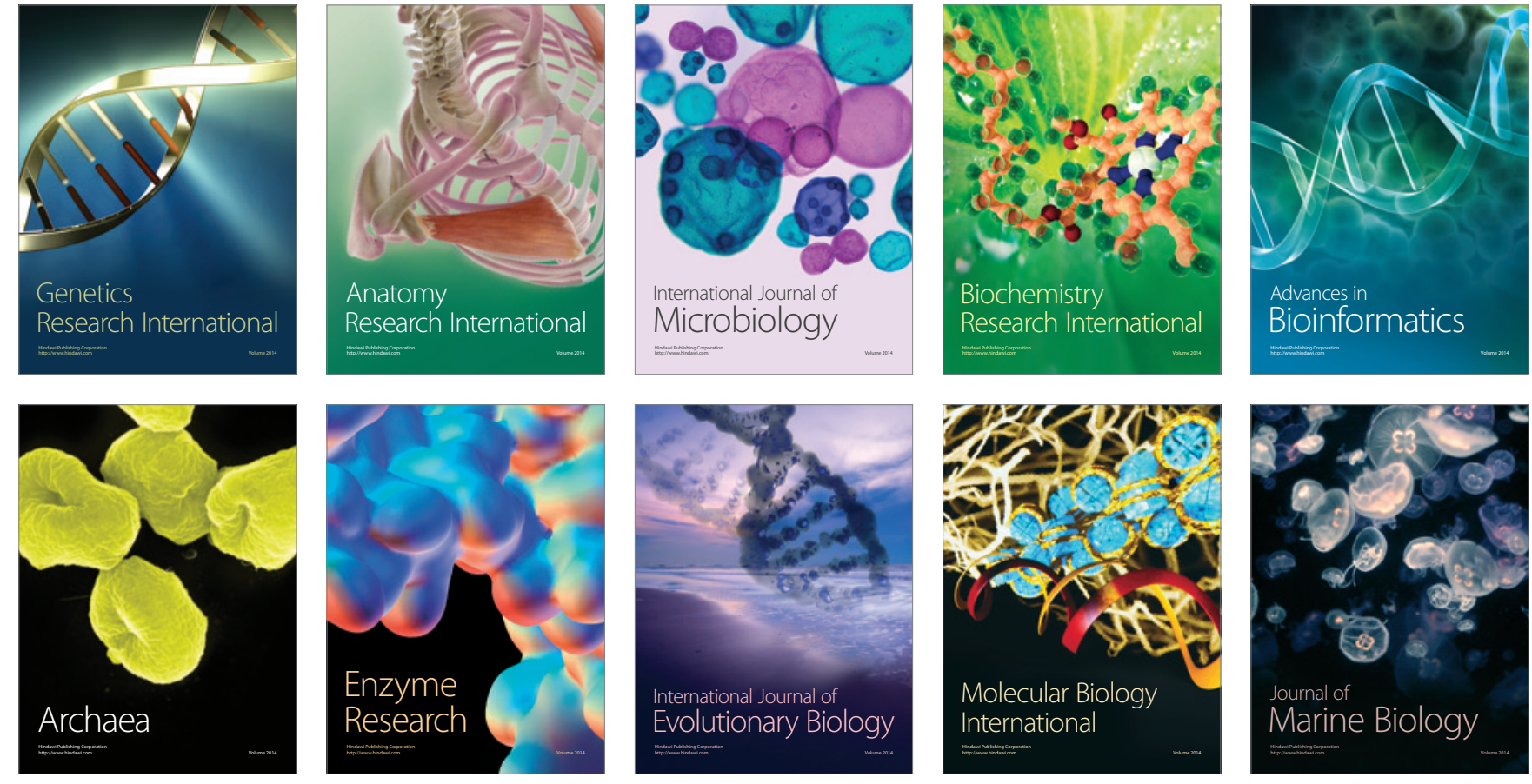